\title{
Hukum Utama Dalam Mempersiapkan Khotbah
}

\author{
Hasanema Wau \\ hasanemawau1969@gmail.com \\ Sekolah Tinggi Teologi Injili Indonesia Lombok
}

\begin{abstract}
A sermon today (here) is built from a text written thousands of years ago and addressed to a specific person or community. Serious efforts are needed to bridge the cultural gap between today's readers and first readers. Two temptations to watch out for: first, focus on exploring and describing various historical arguments. The sermon focuses on patterns of interpretation of the biblical texts relating to the past in the area of Israel and beyond. Second, the focus is to be relevant, so that it ignores what the author intends, what is understood by the recipient of the letter. The Scriptures are not a letter that is only able to be solved by an expert in a line of academic degrees. On the one hand it must find out the meaning of the text (for writers and readers), on the other hand it must find principles that can be applied now and here. Balance is a demand! The Word of God speaks to all generations, so it is not enough to rediscover the original meaning of a passage without describing the significance of the passage for today.
\end{abstract}

Key Words: Sermons, Textuals, Interpretations, Relevant

\begin{abstract}
Abstrak
Sebuah khotbah hari ini (di sini) dibangun dari teks yang ditulis ribuan tahun yang lalu dan ditujukan kepada orang atau komunitas tertentu. Upaya serius diperlukan untuk menjembatani kesenjangan budaya antara pembaca saat ini dan pembaca pertama. Dua godaan yang harus diwaspadai: pertama, fokus mengeksplorasi dan mendeskripsikan berbagai argumen sejarah. Khotbah berfokus pada pola penafsiran teks-teks alkitabiah yang berkaitan dengan masa lalu di wilayah Israel dan sekitarnya. Kedua, fokusnya harus relevan, sehingga mengabaikan maksud penulis, apa yang dipahami penerima surat. Kitab Suci bukanlah surat yang hanya bisa diselesaikan oleh seorang ahli di bidang akademis. Di satu sisi harus mencari tahu makna teks (bagi penulis dan pembaca), di sisi lain harus menemukan prinsip-prinsip yang bisa diterapkan sekarang dan di sini. Keseimbangan adalah permintaan Firman Tuhan berbicara kepada semua generasi, jadi tidaklah cukup untuk menemukan kembali arti asli dari suatu bagian tanpa menjelaskan pentingnya bagian tersebut untuk hari ini.
\end{abstract}

Kata kunci: Khotbah, Teks, Penafsiran, Relevan. 


\section{Pendahuluan}

Sebuah jam (jam tangan atau jam dinding) merek apa saja, bentuk, bahan dan ukuran mana pun, tahan air atau rentan air, import atau produk dalam negeri, harga murah bahkan nilai fantastis, hanya bermanfaat jika fungsinya terpenuhi. Merek dan tampilan penuh gengsi, sering membuat pembeli berpikir panjang untuk akhirnya menentukan pilihan, mau beli yang mana. Kreativitas dan inovasi tiada henti dalam industri jam dengan asesorisasesoris yang menyasar segmen remaja dan anak muda, bahkan anak-anak patut diapresiasi.

Tetapi, pada akhirnya apakah yang paling substansi pada sebuah jam? Ini dia: "Jam tersebut dapat menunjukkan waktu dengan tepat." Ini syarat utama! Penulis pernah memiliki sebuah jam tangan yang ada keterangan water resistence (anti atau tahan air), dan biasanya keterangan serupa merupakan pertanda produknya original atau resmi. Jam tangan water resistence, dan memang terbukti! Namun suatu hari jam tersebut mengalami kerusakan lalu dibawa ke tukang servis jam. Normal lagi! Sayang, beberapa kali bermasalah, dan servis terakhir terdeteksi bahwa mesinnya sudah game over, tidak dapat lagi diperbaiki. Jam yang sebelumnya dibangga-banggakan, sekarang tinggal kenangan. Jadi jika jarum jam tetap berputar dan bergerak dengan arah yang lazim, namun tidak mampu lagi menunjukkan waktu dengan tepat, apakah telat atau kecepatan, maka jam mati masih lebih baik, karena jam mati pasti dua kali benar dalam satu hari. Demikian juga halnya dengan sebuah

${ }^{1}$ Bob Utley, Anda Dapat Memahami Alkitab (Texas: Bible Lessons International, 2009), 25. khotbah. Tidak cukup hanya dengan modal nyali semata. Ada unsur-unsur yang secara mendasar harus terpenuhi.

\section{Benar Sesuai Teks}

Khotbah yang benar meliputi dua hal, yaitu: pertama sumbernya. Khotbah harus bersumber dan dibangun di atas dasar kebenaran Alkitab. Otoritas Kitab Suci mendasari sebuah khotbah yang baik. Sajian-sajian memikat dari internet dapat menggoda untuk merangkai khotbah tanpa menyelidiki teks Kitab Suci dengan baik. Haruslah diingat bahwa Mbah Google hanya sebagai penadah dari siapa saja yang bisa akses dan mengupload apa saja.

Bob Utley, dalam buku Anda Dapat Memahami Alkitab berkata: "Kita sebagai seorang manusia terbiasa dengan mencari kepuasan instan bagi setiap kebutuhan kita. Budaya kita telah mengubah mentalitas industri "fast food" menjadi suatu norma budaya. Kita terbiasa dengan produk yang selalu tersedia dan bisa seketika dikonsumsi. Kedewasaan Kristen berdasarkan pengetahuan Alkitab dan gaya hidup sehari-hari tidak dapat mengakomodasi harapan dari budaya ini."

Tepat yang dikatakan oleh Jerry Vines \& Jim Shaddix dalam buku Kuasa Dalam Berkhotbah: "Yang pertama dan terutama, khotbah bersumber dari Tuhan. Allah telah memutuskan untuk mengungkapkan diri-Nya kepada umat manusia dan Ia memilih manusia sebagai media penyingkapannya."2

Karena apa kata Alkitab adalah perkataan Allah, maka secara

${ }^{2}$ Jim Vines, Jerry \& Shaddix, Kuasa Dalam Berkhotbah (Malang: Gandum Mas, 2002), 22. 
murni harus dijunjung tinggi. Karena itu perlu upaya serius untuk mencari pesan dari para penulis Alkitab yang diilhami, bahkan ketika hal-hal tersebut mungkin melanggar kehendak pribadi atau tradisi-tradisi denominasi tertentu.

Kedua, isinya sesuai ajaran Alkitab itu sendiri. Benar berarti sesuai sebagaimana seharusnya atau dapat dipercaya. Patut disayangkan jika sumbernya sudah benar, tetapi pemaparannya menyimpang dari nilainilai yang sepatutnya. Sebagai contoh, penafsirnya memiliki kompetensi secara akademik, sumbernya sudah benar, yaitu Alkitab. Apakah ada jaminan benar?

William Klein, Blomberg dan Hubard menyikapi hal ini dengan berkata: "Meskipun demikian, kita masih menghadapi sebuah dilema, karena tambahan terhadap metodologi yang akurat, keyakinan atau presuposisi dari sang penafsir tentang natur Alkitab dan tentang natur sesungguhnya dari tugas penafsiran secara mendalam memengaruhi hasil karyanya."3

Dengan kekuatiran yang sama, Douglas Stuart dan Gordon Fee berkata: "Penafsiran yang tepat membutuhkan kebebasan pribadi penafsir, namun kebebasan tersebut disertai dengan berbagai resiko akan terjadinya bias dan penyimpangan."

Seorang yang tidak memercayai mujizat sebagai peristiwa nyata, akan melakukan apa pun untuk memberi solusi secara ilmiah. Yang penting bisa dijelaskan secara ilmiah dan bisa dicerna oleh akal. Sebuah cerita tentang seorang pengkhotbah yang menggagap bahwa mujizat itu mitos.

Beliau berkhotbah dari teks seputar keluarnya Israel dari Mesir,

${ }^{3}$ William W.dkk Klein, Introdukction to Biblical Interpretation 1 (Malang: Literatur SAAT, 2002), 231. yang melewati Laut Teberau. Menurut catatan Alkitab: Orang Israel berjalan dari tengah-tengah laut di tempat kering; sedang di kiri dan di kanan mereka air itu sebagai tembok bagi mereka (Kel. 14:22 bdk Ibr. 11:29). Tetapi sang pengkhotbah menjelaskan bahwa itu adalah gejala alam. Ia berkata: "Tidak ada yang ganjil dalam peristiwa itu. Itu bukan mujizat! Pada saat itu kebetulan laut sedang pasang surut, jadi debit air turun hingga batas lutut, sehingga mereka berhasil menyeberang."

Alasannya sederhana, yaitu:

tidak ada konfirmasi kebenaran berdasarkan kriteria ilmiah. Mujizat beredar di luar orbit analisis ilmiah. Tiba-tiba seorang anak muda yang hadir dalam ibadah itu berkata: "Haleluya! Yang pak Pendeta sampaikan itu juga mujizat, dan ini nampaknya tergolong mujizat baru." Karena tidak lazim terjadi interupsi sementara khotbah, pak Pendeta bertanya dengan nada merasa terganggu, katanya: "Apa yang Anda maksudkan, anak muda?" Si pemuda dengan santai menjawab: "Ternyata air sebatas lutut, dapat menenggelamkan kuda perang dan prajurit-prajurit Mesir."

Bagaimana pendeta yang sama menjelaskan kebangkitan Yesus; peristiwa lima roti dua ikan; lima ribu orang yang makan bahkan tersisa dua belas bakul; Yesus berjalan di atas air? Ya, semuanya legenda! Bagi dia mujizat bertentangan dengan akal. Yang benar adalah mujizat bukan bertentangan dengan akal, telapi melampaui akal. Mengapa? Karena pelakunya Allah yang mahakuasa. Sebagai contoh, jika seorang Presiden berkunjung ke suatu daerah, tentu saja rambu-rambu lalu lintas tidak bisa

${ }^{4}$ Douglas dan Gordon D.Fee Stuart, Hermeneutik (Malang: Gandum Mas, 2015), 3. 
menghalanginya, misalnya sedang menyala lampu merah tanda berhenti, tetap saja diterobos, karena presiden memiliki otoritas untuk itu. Dan tidak seorang pun dari antara para pengguna jalan yang protes, keberatan lalu marahmarah, karena gilirannya diserobot. Bahkan ambulans dan mobil pemadam kebakaran pun mendapat keistimewaan dalam hal ini. Lebih-lebih lagi Allah yang menciptakan akal manusia. Jangan berusaha hingga berdarah-darah menjelaskan supaya Dia masuk akal. "Sebab Dia berfirman, maka semuanya jadi; Dia memberi perintah, maka semuanya ada" (Mzm. 33:9). Mazmur 148:5 mencatat: "Baiklah semuanya memuji nama TUHAN, sebab Dia memberi perintah, maka semuanya tercipta." Yohanes di pulau Patmos menyerukan, seperti ini: "Ya Tuhan dan Allah kami, Engkau layak menerima puji-pujian dan hormat dan kuasa; sebab Engkau telah menciptakan segala sesuatu; dan oleh karena kehendak-Mu semuanya itu ada dan diciptakan" (Why. 4:11). Inilah persoalan yang krusial. William Klein dan kawan-kawan berkata:

Tidak seorang pun menafsirkan sesuatu tanpa seperangkat asumsi yang menjadi dasar pemikirannya. Ketika kita berusaha menjelaskan makna dari Alkitab, kita, melakukannya dengan seperangkat ide yang sudah ada sebelumnya atau berbagai presuposisi. Semua presuposisi tersebut mungkin saja dinilai dan diungkapkan secara terbuka, atau mungkin saja dipegang secara tidak sadar. ${ }^{5}$

Dalam kehidupan seharihari, setiap orang memilki pemahaman atau anggapan terhadap apa yang ada di dunia ini berdasarkan pengalaman, pelatihan, dan pemikiran yang sudah dimiliki sebelumnya, dan ia menafsirkan pengalaman-pengalaman tersebut berdasarkan pemahamanpemahaman awal yang sudah ia miliki. Semua itu mungkin saja benar atau salah - atau sebagian benar - namun semuanya itu menyaring dan mewarnai segala sesuatu yang ia hadapi. Percuma berkhotbah tentang kuasa Firman Tuhan yang mengubah hidup jika berpikir bahwa ayat-ayat tersebut hanya produk manusia yang sarat kesalahan. Rasul Petrus mencatat: “..... seperti juga Paulus, saudara kita yang kekasih, telah menulis kepadamu menurut hikmat yang dikaruniakan kepadanya. ... Dalam surat-suratnya itu ada hal-hal yang sukar difahami, sehingga orangorang yang tidak memahaminya dan yang tidak teguh imannya, memutarbalikkannya menjadi kebinasaan mereka sendiri, sama seperti yang juga mereka buat dengan tulisan-tulisan yang lain" (2Ptr. 3:1516).

Petrus sendiri mengakui bahwa ada kesulitan-kesulitan dalam memahami catatan-catatan dalam Alkitab. Karena alasan ini sejumlah pakar Alkitab menulis buku yang menyajikan jawaban, secara khusus teks-teks yang pelik dan sukar. Sebut saja Ucapan Paulus yang Sulit (Manired T. Brauch); Ucapan Yesus yang Sulit (F.F. Bruce); Ucapan Perjanjian Lama yang Sulit (Walter C. Kaiser) dan sebagainya. Betapa pun sukarnya, sebagai seorang pengkhotbah harus bertanggung jawab kepada sang Pengutus, yaitu Allah sendiri. Di atas segalanya Dia yang selalu menjadi pusat pemberitaan. Jika Allah senang niscaya umat diubahkan. Tetapi kalau

${ }^{5}$ Klein, Introdukction to Biblical Interpretation 1, 245. 
umat senang, belum tentu Allah mendapat porsi yang sama.

Sebuah baliho milik salah seorang tokoh politik sebagai bakal calon kepala daerah dalam Pemilukada berdiri tegak di sejumlah titik di suatu provinsi dengan tulisan "Yang Penting Rakyat Senang." Sebagian orang bersikap sinis dan terkesan mencibir, namun sah-sah saja tertulis demikian, namanya juga politik. Pengkhotbah bukan politikus yang sedang mencari panggung untuk sebuah popularitas.

Dengan motif tertentu bisa tergoda untuk berkata "yang penting jemaat senang." Ini bahaya paling serius dan mematikan! Menjadi motivator Kristen dan pengkhotbah sejati adalah hal yang berbeda sama sekali. Motivator Kristen baca ayat, cerita yang lain, asal semangat, menarik dan lucu, jemaat pulang dengan hati senang, terhibur dan dipuaskan.

Gereja diperlakukan sebagai wadah untuk kepuasan pelanggan (jemaat). Mark Labberton dalam buku Bahaya Ibadah Sejati berkata: "Kita menciptakan Allah yang memberkati kita tanpa memberi tanggung jawab, yang mengijinkan kita merasakan hadirat-Nya tanpa menghidupi kehidupannya, yang selalu memihak kita dan tidak pernah melawan kita, yang memberi kita apa saja yang kita inginkan, tiap kali kita mengingankannya."

Memilih

menyenangkan

menyenangkan

Allah atau

mempersiapkan dan menyampaikan khotbah dikemas secara atraktif oleh motif. Catat baik-baik: "Hanya Allah yang layak disenangkan!"

Seorang pianis ternama diundang bermain piano dalam sebuah konser akbar. Pianis handal ini telat datang, dan hadirin sudah mulai gelisah. Akhirnya dia datang juga dan langsung mempertontonkan kebolehannya. Selesai durasi yang disepakati, sang pemusik berhenti. Namun para hadirin masih menginginkannya dengan berteriak histeris, lagi, lagi dan lagi.

Ketua panitia mendekatinya dan berkata ayo lanjutkan, mereka semua berdiri menyambut Anda pertanda senang. Si pianis melihat ke arah hadirin dan ternyata ada satu orang yang tetap duduk. Kemudian dia berkata kepada ketua panitia: "Oh tidak semua berdiri, itu masih ada yang tetap duduk." Ah...itu sih orang tua, tidak usah digubris, lihatlah orang banyak yang antusias ini, jawab ketua panitia. "Tetapi yang tetap duduk itu adalah guru saya," sahut sang pianis. Sebuah pukulan telak!

Penulis sering mendapat sambutan yang memuaskan ego berupa tepuk tangan para pendengar, jabat tangan yang disertai kata-kata, "terima kasih, saya sangat diberkati dengan pelayanan bapak." Penghargaanpenghargaan berupa pujian, ucapan terima kasih, tepukan tangan, traktir makan, amplop persembahan kasih dan sebagainya sah-sah saja. Tetapi yang menjadikan pelayanan itu bernilai kekal adalah jika Allah disenangkan.

Apakah pertolongan yang tersedia, supaya beritanya benar sebagaimana maksud teks? Ada sejumlah faktor yang mewajibkan pembaca, terlebih lagi para penafsir bekerja lebih keras. Pengkhotbah menghadapi dua realitas dasar: teks Alkitab dari abad permulaan dan konteksnya di abad modern. Beberapa pengkhotbah menekankan teks, tetapi menjadikan tidak relevan untuk konteks modern. Yang lain menekankan konteks modern dan tidak setia kepada

${ }^{6}$ Mark Labberton, Bahaya Ibadah Sejati (Surabaya: Perkantas, 2007), 83. 
teks. Unsur-unsur berikut mutlak menjadi perhatian.

\section{Pertama, Masa Penulisan.}

Sejarah Alkitab ditulis dalam rentang waktu yang begitu panjang, ribuan tahun. Antara masa penulisan Kitab Suci dengan dunia pasca modern terbentang jurang sejarah yang lebar, dari ratusan tahun hingga ribuan tahun.

Douglas Stuart dan Gordon

Fee berkata: "Penafsiran Alkitab dibutuhkan karena ketegangan" yang ada di antara relevansi kekalnya dengan keistimewaan historisnya." 7 Dalam buku Introduction Biblical Interpretation, William Klein, Craig Blomberg dan Robert Hubard sepakat dengan berkata: "Perintah-perintah Allah bersifat absolut, namun semuanya dibatasi oleh kontekskonteks sejarah yang sangat berbeda, sehingga amat sulit bagi kita untuk menerimanya sebagai hal yang normatif secara universal." ${ }^{8}$

Geografi. Alkitab ditulis di negeri yang lain. Ditulis lebih dari 40 orang dari segala lapisan masyarakat yang berbeda dalam pendidikan dan latar belakang. Selain nabi, para penulis ini bisa disebut sebagai: raja, petani, ahli filsafat, nelayan, pujangga, negarawan, cendekiawan, dan lain-lain. Contohnya: Musa seorang pemimpin politik, sebagai pangeran Mesir, Musa pasti mendapatkan pendidikan terbaik dari "Universitas" di Mesir. Petrus seorang nelayan, Amos seorang gembala, Yosua seorang panglima perang, Nehemia, seorang pembawa minuman raja, Daniel, seorang perdana menteri, Lukas, seorang dokter, Salomo atau Daud yang adalah raja, Matius, seorang penagih pajak, Paulus, seorang rabbi dan sebagainya.

Bagi penerima kitab mula-

${ }^{7}$ Stuart, Hermeneutik, 17. mula, Alkitab jelas tidak sesulit seperti yang kita alami sekarang. Mereka berbagai latar belakang kultural, lingusitik, historis, politis, dan geografis yang sama dengan para penulis Alkitab. Kalau pun ada bagianbagian tertentu yang tetap dianggap sulit, tingkat kesulitannya tidak akan sebesar yang dihadapi sekarang. Penulisannya pun tersebar di berbagai tempat yang berbeda, di antaranya: Musa di padang gurun, Yeremia di rumah tahanan, Daniel, di istana dan di lereng-lereng gunung, Paulus di balik sel penjara, Lukas dalam perjalanan, Yohanes di pulau Patmos dan sebagainya.

Selain itu sudah pasti bahwa para penulis Alkitab berhadapan dengan siatuasi politik, ekonomi, sosial dan keagamaan pada masa itu. Sebagai sebuah kitab kuno, Alkitab ditulis dalam konteks politis, historis, kultural, dan geografis tertentu. Tidak semua konteks ini dapat ditelusuri kembali berdasarkan peninggalan arkheologis maupun tulisan-tulisan kuno yang ada. Jurang inilah yang menyebabkan ada ruang cukup lebar bagi ketidakpastian dan perbedaan pendapat.

Kultur. Alkitab ditulis dalam budaya yang berbeda dari sekarang. Sebuah fakta bahwa Alkitab tidak ditulis langsung untuk komunitas zaman now. Kecenderungan berpikir bahwa insan modern yang disasar oleh penulis, akan berujung pada pembiaran konteks dan latar belakang teks.

Sesungguhnya terdapat beragam jurang antara penerima mulamula dan pembaca sekarang, sebut saja jurang bahasa, budaya, historis, geografis, dan sebagainya. Gampang memahami hal ini jika membandingkannya dengan budaya

${ }^{8}$ Klein, Introdukction to Biblical Interpretation 1, 3 . 
modern. Telah banyak yang berubah

sejak dua puluh tahun yang lalu hingga

kini dan juga dapat meramalkan bagaimana situasi dalam dua puluh tahun mendatang. Pasti beda! Pembaca-pembaca Alkitab masa kini dan pembaca-pembaca mula-mula dari zaman Alkitab dipisahkan oleh kesenjangan budaya yang amat besar.

Alkitab dengan budaya Laut Tengah pada umumnya dan Palestina khususnya, demikian terasa perbedaan dengan kebudayaan modern. Dibanding dengan daerah itu saja dulu dan kini, terlebih berbeda lagi dengan budaya Alkitab zaman itu dengan kini dan di sini. Struktur sosial, latar belakang para penulis, sistem ekonomi, ilmu pengobatan yang masih primitif dan sebagainya.

Ada jurang budaya yang membuat cara hidup dan cara berpikir para penulis Kitab Suci dan masyarakat mereka berbeda tajam dari cara-cara masyarakat pasca modern ini untuk hal-hal yang sama. Musa dan Yesus dari Nazareth serta rasul Paulus misalnya, tak mengenal berbagai jenis komputer, gadget, Internet dan Twitter, tidak seperti masyarakat yang hidup di abad ke-21 ini. Ini mutlak benar, karena: "Tidak ada kebudayaan yang ditetapkan oleh Allah; kebudayaankebudayaan sesungguhnya berbedabeda, bukan hanya dari abad pertama sampai abad ke 21, tetapi juga di abad ke-21 itu sendiri." ${ }^{9}$ Kuda-kuda perang di zaman Alkitab kini hanya cocok di arena pacuan kuda fungsinya telah diambil alih oleh tank-tank dan pesawat tempur. Bahkan yang relatif modern seperti meriam dengan jarak tembak terbatas hanya dapat disaksikan di museum militer, sudah diganti dengan peluru kendali yang

\footnotetext{
${ }^{9}$ Stuart, Hermeneutik, 70.
}

dioperasikan dengan komputer dari jarak ratusan bahkan ribuan kilometer. Alat transportasi seperti keledai, unta, kuda telah beralih ke mobil, kereta cepat, pesawat dan sebagainya. Kitab Suci pun mengalami perkembangan bentuk dari tulisan asli, salinan, cetak, photocopy, komputer meja, laptop, gadget hingga telepon genggam android. Entah apa lagi setelah ini! Dalam buku Culture Making, Andy Crouch berkata:

Cara kita berbicara tentang kebudayaan, bagaimana ia bekerja, berubah dan memengaruhi kita serta apa yang kita harapkan darinya sering tidak menolong kita. Kita berbicara tentang "kebudayaan tertentu" (tunggal) meskipun kebudayaan sebenarnya selalu jamak: penuh keragaman, variasi, dan sejarah. Kita berbicara tentang kebudayaan seolah intinya, ia adalah seperangkat ide, padahal inti utamanya, ia adalah seperangkat hal yang nyata. ${ }^{10}$

Bahasa. Alkitab ditulis dalam bahasa Ibrani, Yunani dan Arami. Dalam buku Pedoman Penafsiran Alkitab, John H. Hayes \& Carl R. Holladay mencatat: "Bahkan orang Israel modern yang berbicara dalam bahasa Ibrani atau orang Yunani modern yang berbicara bahasa Yunani mengakui bahwa bahasa-bahasa Alkitab tidaklah sama dengan bahasa Ibrani dan Yunani. Meskipun seorang pakar Perjanjian Baru, Doktor Petrus Maryono mencatat bahwa: "Bahasa Yunani Perjanjian Baru tidak lain adalah bahasa sehari-hari masyarakat kala itu; karena itu disebut bahasa

${ }^{10}$ Andy Crouch, Culture Making (Surabaya: Literatur Perkantas Jatim, n.d.), 10. 
Yunani Koine." ${ }^{\prime 11}$ Para penafsir modern dalam menafsir Alkitab, menemukan masalah berupa kendala bahasa. Dalam buku Spiral Hermeneutika, Grant Osborn berkata:

"Alkitab tidak diwahyukan melalui "mulut para malaikat." Walaupun diinspirasikan oleh Allah. Alkitab ditulis dalam bahasa manusia dan di dalam budaya-budaya manusia. Mengikuti natur dari bahasa, maka kebenaran-kebenaran yang mutlak dari Kitab Suci dibungkus dalam bahasa dan budaya orang Ibrani dan Yunani kuno, dan kita harus memahami budaya-budaya tersebut untuk menafsir teks-teks Alkitab secara tepat. ${ }^{12}$

Alkitab ditulis oleh beberapa pengarang, ditujukan kepada bermacam-macam pembaca (kelompok pembaca) di zaman tertentu. Mereka berbicara pada orang Israel yang tinggal di Timur Tengah, pada zaman tertentu sehingga tidak luput dari pengaruh zaman dan tempat mereka hidup. Ditulis dengan maksud tertentu dalam situasi tertentu. Jika membaca dan menafsir kini dan di sini, berarti sedang membaca dan menafsir surat orang lain. Pembaca modern hadir dan bertindak sebagai pihak ketiga.

Kedua, Maksud Penulis Jelas

Bagi Penerima. Sebuah teks tidak dapat memiliki arti yang tidak pernah penulis teks tersebut maksudkan.Bahkan meskipun kelihatan uraian, ulasan atau pemaparannya memberkati pendengar, tetap saja kesetiaan pada teks menjadi

\footnotetext{
${ }^{11}$ Petrus Maryono, Gramatika \& Sintaksis Bahasa Yunani Perjanjian Baru (Yogyakarta: STTII Yogyakarta, 2016), 10.

${ }^{12}$ Grant R Osborne, Spiral Hermeneutika (Surabaya: Momentum, 2012), 4.
}

korban. Willam Kein, Craig Blomberg dan Robert Hubbart sependapat bahwa: "Mereka yang membaca Alkitab hanya berdasarkan perspektif kondisi-kondisi sesaat, yang lupa bahwa bagian tulisan tersebut aslinya dituliskan untuk orang lain, telah memperpendek proses penafsiran dan, oleh sebab itu, kehilangan sesuatu yang sungguh dikatakan oleh teks." ${ }^{13}$ Lebih lanjut ketiga penulis buku yanga sama dan satu ini berkata: "Setiap bentuk komunikasi lisan atau tulisan mengandung tiga jenis makna: (1) apa yang dimaksud pembicara atau penulis lewat apa yang ia katakan atau tuliskan; (2) apa yang sesungguhnya dipahami penerima dari pernyataan tersebut; (3) dalam pengertian yang abstrak, makna apa yang sebenarnya tersirat di dalam teks atau ucapan itu sendiri." ${ }^{14}$

Ketika Paulus menulis kepada orang-orang di zamannya, ia mengharapkan mereka mengerti apa yang ia maksud. Mekipun diperlukan sebuah pengarahan, namun pembaca perdana tidak berkata: "Saya bingung apa yang ia maksudkan." Mungkin beberapa orang memilki pertanyaan lebih lanjut, tetapi makna dari permasalahannya jelas bagi mereka.

Rambu-rambu lalu lintas di persimpangan jalan padat yang ramai kendaraannya sudah sama-sama dipahami, baik oleh pihak pengguna jalan maupun pihak penegak peraturan lalu lintas. David M. Howard, penulis buku Kitab-kitab Sejarah Dalam Perjanjian Lama berkata:

Ada tiga unsur utama dalam

\author{
${ }^{13}$ Klein, Introdukction to Biblical \\ Interpretation 1, 11 . \\ ${ }^{14}$ Ibid., 12
}


cerita-cerita yang biasanya dibahas, yaitu: alur cerita, tokoh, dan latar (tempat kejadian). Kita menyebutnya unsur-unsur internal (unsurunsur dalam cerita). Tetapi untuk memahami hal tersebut, kita perlu juga memperhitungkan hadirnya pencerita (pengarang), dan khalayak (pembaca) serta cerita itu sendiri dari sudut pandang tertentu (unsur-unsur eksternal - tidak langsung dapat terlihat dalam cerita). ${ }^{15}$

Dalam pemaparan lebih lanjut, Howard menulis: "Pengarang mungkin ingin mengatakan lebih banyak mengenai topik tertentu dibanding dengan yang terungkap dalam naskah. Namun, untuk maksud-maksud pembacaan naskah, kita dibatasi oleh apa yang tertulis saja."16

Jika membaca rambu-rambu lalu lintas atau penunjuk arah, siapa penulis tidaklah menjadi masalah. Yang penting bahwa pembaca dan teks dari rambu atau peunjuk arah dimaksud sama-sama memiliki media acuan bahasa yang sama.

Grant Osborn mengakui dilema ini ketika berkata: "Masalahnya adalah meskipun para penulis asli mempunyai satu makna tertentu dalam benaknya ketika mereka menulis, namun sekarang makna tersebut sudah tidak ada pada kita karena para penulis tersebut tidak lagi hadir untuk memastikan dan menjelaskan apa yang mereka tulis."17

Fakta bahwa manusia modern tidak melihat dan tidak mendengar mereka yang diajak bicara

${ }^{15}$ David M Howard, Kitab-Kitab Sejarah Dalam Perjanjian Lama (Malang: Gandum Mas, 2002), 57.

${ }^{16}$ Ibid., 57.

${ }^{17}$ Osborne, Spiral Hermeneutika, oleh penulis (misalnya Paulus). Seumpama sedang mendengar satu pihak melakukan percakapan via telepon, siapa pun tidak dapat memastikan bagaimana respon atau reaksi orang di ujung telepon lainnya.

Paling serius mencoba berandai-andai dan menebak atau menduga seluruh percakapan melalui perkataan satu pihak. Nah tiap orang bisa bervariasi asumsinya. Marilah berkata dengan jelas: Teks itu hanya mempunyai satu makna, yaitu makna yang dimaksudkan oleh penulisnya; dan hanya ada satu cara untuk mengungkapkan makna itu, yaitu metode tata bahasa dan sejarah. ${ }^{18}$

Adapun mengenai latar belakang sejarah dari suatu teks, pertama-tama harus menanyakan apa yang dimaksudkan oleh penulis? Sebab hanya jika memahami maksud suatu bacaan dalam zaman penulisnya, barulah dapat menangkap arti sepenuhnya dari bacaan tersebut bagi iman dan kehidupan Kristen.

Jadi sekiranya makna dari sebuah teks sudah diperoleh, dari hasil usaha terbaik, baru bisa melangkah ke elemen kunci kedua dari hermeneutika: menyelidiki signifikansinya pada masa kini." Yang menjadi fokus adalah berkenaan dengan pemakaian kata-kata dalam bahasa aslinya, apa yang ditangkap dan dimengerti oleh para pendengar ketika penulis berbicara atau menulis? Apa pengaruh dari pengetahuan tentang sejarah, tatanan sosial dan latar belakang geografisnya, dan tujuan penulisannya terhadap pemahaman kita tentang pesan yang disampaikannya. ${ }^{19}$

Dalam kehidupan sehari-



5. 
hari kerap terjadi kesalahan informasi karena gagal faham. Miskomunikasi kadang tidak terbendung, yang kemudian menuntut klarifikasi. Nampaknya mengerti sedikit lebih baik daripada salah mengerti. Misalnya, siapakah penunggang kuda putih dalam Wahyu 6:2? Dan aku melihat: sesungguhnya, ada seekor kuda putih dan orang yang menungganginya memegang sebuah panah dan kepadanya dikaruniakan sebuah mahkota. Lalu ia maju sebagai pemenang untuk merebut kemenangan (Why. 6:2). Pengalaman di dalam kelas, sejumlah mahasiswa mengaku bahwa sekian lama tahunya penunggang kuda dalam teks itu adalah Kristus.

Asumsinya adalah kuda putih, panah, dikaruniakan sebuah mahkota, maju sebagai pemenang layak disandang oleh Kristus. Terlebih lagi jika membaca Wahyu 19:11, Lalu aku melihat sorga terbuka: sesungguhnya, ada seekor kuda putih; dan Ia yang menungganginya bernama: "Yang Setia dan Yang Benar", Ia menghakimi dan berperang dengan adil. Sama-sama menunggang "kuda putih."

Pengamatan sekilas segera nampak bahwa penunggang kuda putih dalam Wahyu 6:2 adalah Antrikristus. Dalam pasal tersebut Kristus digambarkan sebagai Anak Domba. Berbeda dengan penunggang kuda putih dalam Wahyu 19:11, bernama ""Yang Setia dan Yang Benar,"sebuah sebutan yang tepat untuk Yesus.

Tugas utama dan terakhir dalam penafsiran adalah: Pertama, memahami sejelas mungkin apa yang dikatakan oleh para penulis Alkitab pada zaman mereka. Kedua, mencari tahu apa yang telah dipahami oleh para pendengar aslinya. Ketiga, bagaimana kebenaran-kebenaran ini berlaku bagi budaya dan kehidupan pribadi dalam kekinian. Bagaimana supaya khotbah yang dipaparkan sedapat mungkin mencerminkan ketiga hal di atas? Langkah paling menentukan adalah berusaha mengenal kedua kultur, budaya penerima surat dan kultur pendengar khotbah di masa kini dengan baik.

Hanya memperhatikan dan membaca setiap teks belumlah cukup untuk menangkap maksud penulis. Apa yang dikuatirkan oleh Roy B. Zuck berpotensi menjadi nyata. Ia berkata: "Ketika membaca bagian-bagian dari Alkitab, banyak orang merasa kebingungan tentang makna dari apa yang dibacanya atau berakhir dengan mendapatkan pemahaaman yang keliru." 20

Interpretasi mungkin adalah langkah yang paling sulit dan paling memakan waktu (dibanding dengan observasi dan penerapan). Meskipun demikian, mempersingkat telaah Alkitab dalam bidang ini bisa menyebabkan kesalahan fatal dan hasil yang tidak benar. ${ }^{21}$

Gambarannya seperti ini: di sebuah jemaat lokal, terjadi beberapa kali kasus asusila (perzinahan) yang terkonfirmasi melalui pengakuan dosa kepada Imam atau Pastor. Lalu pastor dan tua-tua jemaat sepakat untuk memperhalus istilah tersebut dengan menggunakan kata "jatuh." Semua warga jemaat setuju. Suatu ketika pastor jemaat pindah dan digantikan oleh pastor yang baru. Sebagaimana biasa pada acara pengakuan dosa, warga jemaat bergantian untuk mengaku dosa yang kemudian didoakan oleh pastor. Awalnya sang pastor bingung mendengar pengakuan dari beberapa anggota jemaat yang mengaku telah "jatuh." Tambah bertanya-tanya, 
karena pengakuan serupa terjadi berkali-kali. Akhirnya Pastor menelpon Walikota dengan berpesan agar jalanjalan di kota segera diperbaiki, karena banyak orang jatuh, termasuk warga jemaat. Terang saja Walikota yang adalah juga warga jemaat tertawa lepas, ketika mendengar berita tersebut, karena ia tahu bahwa tidak ada hubungan pengakuan jatuh itu dengan kondisi infrastruktur jalan. Pastor menutup telpon dengan berkata, "Mengapa Anda malah tertawa? Minggu ini saja istri Anda jatuh dua kali." Kata yang sama dan satu dimaknai secara beragam atau berbeda oleh pihak-pihak yang berkepentingan.

Dalam hal penafsiran Alkitab, semua yang dianggap sangat penting seperti penyelidikan latar belakang sejarah, konteks budaya, siapa penulis dan penerima pertama dari suatu surat atau kitab tertentu di dalam Alkitab harus selalu menempati tempat utama di dalamnya.

Hal ini harus dilakukan oleh karena setiap penulis memiliki cara pandang, sikap, perilaku, perasaan dari setiap pemeran yang dimunculkan di dalam ceritanya. Harus diakui bahwa Alkitab berasal dari dalam konteks yang secara kronologis terpisah jauh dari masa kini. Selain itu bahan-bahan dari Alkitab terbentuk dalam kurun waktu yang demikian panjang, maka kontekskonteks sejarah yang berlain-lainan di dalamnya pelbagai ragam kitab dan tradisi terbentuk perlu dipahami. Dengan memahami jurang yang terjal seperti itu, teks-teks Kitab Suci yang dikhotbahkan di era pasca modern ini dapat menjadi khotbah yang kontemporer.

Perbedaan-perbedaan ini merupakan gap/jurang bagi pengertian orang zaman sekarang untuk mengerti maksud sebenarnya dari pengarang waktu itu. Pendengar di era pasca modern bukanlah penerima langsung nats-nats yang diangkat sebagai acuan atau bangunan khotbah. Bukankah kultur kita terus berubah?

David M. Howard, dalam buku Kitab-kitab Sejarah Dalam Perjanjian Lama berkata: "Pada zaman modern ini, adalah sangat membantu jika perbedaan-perbedaan antara pembaca dan pembaca tersembunyi dipertahankan, sebab naskah Alkitab semula tidak ditujukan bagi kita. Tugas kita ialah menempatkan diri ke dalam dunia dan sebanyak mungkin ke dalam pikiran pembaca tersembunyi." 22

Beberapa konteks dan isi dari pertanyaan yang harus ditelusuri seseorang dari setiap naskah Alkitab: pertama, apa yang dikatakan penulis asli? (kritik kenaskahan); kedua, apa yang dimaksudkan si penulis asli? (eksegesis); ketiga, apa yang dikatakan si penulis asli di tempat lain tentang pokok bahasan yang sama? (bagianbagian paralel); keempat, apa yang dikatakan para penulis Alkitab lainnya tentang subyek yang sama? (bagianbagian paralel); kelima, bagaimana para pendengar asli tersebut memahami pesannya dan menanggapinya? (aplikasi asli); keenam, bagaimana pesan asli tersebut bisa diterapkan untuk zaman saya? (aplikasi modern); ketujuh, bagaimana pesan asli tersebut bisa diterapkan untuk hidup saya? (aplikasi pribadi). ${ }^{23}$

Tetapi bagaimana teks yang ditulis kepada orang atau komunitas tertentu pada zaman tertentu menjadi bias artinya pada masa kini? Tak terbantahkan bahwa dalam mengungkap apa yang tertulis, seseorang telah memiliki berbagai

\footnotetext{
${ }^{22}$ Howard, Kitab-Kitab Sejarah Dalam Perjanjian Lama, 59.
}

${ }^{23}$ Utley, Anda Dapat Memahami

Alkitab, 29. 
prasangka. Terlalu mudah untuk melihat apa saja yang ingin dilihat dalam Alkitab. Sangat mudah untuk memaksakan ide-ide sendiri ke dalam Alkitab alih-alih mengeluarkan dari Kitab Suci apa yang diajarkannya. Masuk akal jadinya jika sebagian orang Kristen, dalam menafsirkan Alkitab, mengandalkan, pencomotan nats mengalegorikan (mencari makna rohani/moral di balik apa yang tertulis), indoktrinasi denominasional dan pengalaman pribadi.

\section{Penafsiran}

Alkitabiah adalah suatu proses spiritual dan rasional, yang berupaya untuk memahami pikiran penulis yang diilhami Tuhan di zaman dahulu sedemikian hingga berita dari Tuhan itu dapat dimengerti dan diterapkan pada zaman kita sekarang ini. Mengapa disebut sebagai proses spiritual? Bob Utley menjelaskan penyebabnya dengan berkata:

Proses ini melibatkan sifat keterbukaan dan kepasrahan kepada Tuhan. Harus ada kelaparan (1) akan Dia, (2) untuk mengenal-Nya, dan (3) untuk melayani-Nya. Proses ini memerlukan doa, pengakuan dan kesediaan untuk merubah gaya hidup. Peranan Roh sangatlah menentukan dalam proses penafsiran ini, namun mengapa banyak Kristen yang sungguhsungguh dan hidup kudus memahami Alkitab secara berbeda adalah suatu misteri. ${ }^{24}$

Proses rasional lebih mudah untuk dijelaskan. Sikap yang konsisten adil terhadap suatu naskah dan tidak boleh terseret oleh pandangan-pandangan yang bersifat denominasional ataupun kepribadian harus tetap bersemi. Setiap orang secara historis telah dipengaruhi oleh suatu pandangan tertentu, sehingga godaan untuk tidak netral dan tidak obyektif sangat mungkin.

Douglas Stuart dan Gordon D. Fee berkata: "Dalam banyak gereja Injili, perempuan dilarang khotbah di gereja (1Kor. 14:34-35), tetapi gereja yang sama segala hal lainnya ditentang sebagai tidak berlaku untuk abad 21. Mengapa ayat 3435 berlaku untuk semua masa dan semua kebudayaan, sedang ayat 1-5; 26-33 dan 39-40 yang memberi peraturan bagi hal bernubuat dan berbicara dalam bahasa Roh hanya berlaku untuk gereja abad pertama. ${ }^{25}$

Polarisasi telah mewarnai sejarah kekristenan. Satu di antara begitu banyak aliran yang bukan saja berbeda, bahkan berseberangan itu adalah pertentangan antara John Calvin (15091564) dan Jakobus Armenius (1560-1609) perihal doktrin keselamatan. John Calvin mengedepankan kedaulatan Allah dalam memilih orang-orang percaya, sementara Jakobus Armenius mengetengahkan kehendak bebas manusia dalam memilih untuk percaya.

Hingga hari ini para pengikut dan pejuang ajaran kedua tokoh ini mengasosiasikan diri dengan sebutan Calvinis dan Armenian. Mudah mengenal dan menandai mana gereja atau sekolah teologi yang bercorak ajaran Calvin dan mana yang bernuansa Armenian.

Apa yang sesungguhnya dimaksud oleh penulis teks menjadi bias oleh pandangan si penafsir? Kekristenan memiliki keragaman pandangan soal baptisan, penggunaan karunia Roh Kudus, Perjamuan Kudus dan sebagainya. Ini nyata! Tentu saja para penulis asli teks (Paulus, Matius, Yakobus, Lukas, Petrus dan yang lainnya) tidak pernah berpikir 
atau berasumsi, apalagi berharap bahwa "suatu saat" apa yang mereka tuliskan akan menjadi ajang perdebatan.

Pasti juga absen di pikiran mereka bahwa tulisan-tulisan tangan mereka itu menjadi objek penelitian para pakar teologi atau para ahli bahasa, maupun para misionaris. Di kalangan umat dan para penafsir sendiri terdapat persoalan serius, karena: pertama, bertebarannya hasil penafsiran; kedua, relativitas dari penafsiran-penafsiran, ketiga absennya kelenturan denominasional yang terhubung dengan penafsiran-penafsiran tertentu, dan keempat, kurangnya kemampuan untuk memverifikasi apa yang telah diberitahukan pada mereka dalam nama Tuhan.

Keterbatasan bahasa manusia turut memengaruhi, bahkan memperumit proses penelusuran akan "apa yang penulis asli katakan?" Bahasa manusia yang pada dasarnya merupakan seperangkat hubungan analog antara katakata dan konsep-konsep, digiring untuk menggambarkan Allah dan hal-hal rohani, tentu menimbulkan masalah. Bahasa manusia menjadi semakin rumit ketika dimasukkan ke dalam bentuk tertulis. Begitu seringnya suara atau gerakan tubuh membantu memahami seluk-beluk komunikasi manusia, tetapi hal-hal ini tidak ada dalam sebuah naskah tertulis.

Pengkajian Alkitab akan dibatasi oleh kerancuan-kerancuan ini, serta juga permasalahan tambahan yaitu menerjemahkan tiga bahasa yang terpisah (Ibrani, Aram, dan Yunani Koine). Harus ada upaya serius untuk dapat mengetahui dengan pasti arti selengkapnya dari setiap bagian.

Kadang-kadang tujuan penulisan surat mudah dilacak, karena memang dinyatakan secara jelas. Misalnya, 1Yohanes 5:13 berbunyi: "Semuanya itu kutuliskan kepada kamu, supaya kamu yang percaya kepada nama Anak Allah, tahu, bahwa kamu memiliki hidup yang kekal." Tujuannya jelas, bukan? "Supaya setiap orang yang percaya kepada nama Anak Allah (Yesus Kristus) tahu, bahwa ia memiliki hidup yang kekal"

Tujuan penulisan juga dapat disisir dari struktur kitab yang jelas untuk dilihat (kitab Efesus), namun kebanyakan menuntut upaya pendalaman supaya dapat menyimak struktur dan tujuan penulis. Dalam kaitannya dengan khotbah, pengkhotbah patut mempertimbangkan, pertama, sebelum mengetahui apa yang dikatakan teks, belum siap, mengartikan teks. Kedua, setiap kata atau frasa pada umumnya mempunyai satu arti, tetapi banyak aplikasi. Pada kenyataannya seorang pun tak dapat menghindar dari penafsiran yang sudah dipagari oleh presuposisi dan pemahaman awal. Jadi subyektifitas dan seperangkat asumsi personal turut memainkan peranan.

Grant Osborn dalam buku

Spiral Hermeneutic, berkata:

Setiap orang dalam menafsirkan membawa seperangkat "prapemahaman," yaitu keyakinan-keyakinan dan ide-ide yang diwariskan dari latar belakang orang itu dan paradigma komunitas. Kita jarang sekali membaca Alkitab untuk menemukan kebenaran; kita lebih sering berusaha untuk menyelaraskannya dengan sistem keyakinan kita dan melihat maknanya di dalam terang pemahaman sistem teologi yang 
telah kita miliki sebelumnya. ${ }^{26}$

Sebuah khotbah butuh kejelasan. Kejelasan akan berdampak pada kemampuan hadirin untuk menyerap dan mencerna isi khotbah. Jelas bicara soal tema, pokok pikiran, alur dan penerapan khotbah.

Dalam buku Moody Handbook of Preaching, Michael Milco, menulis, demikian: "Dalam sebuah khotbah yang baik, poin-poinnya terjalin dengan kuat, transisi-transisinya pas seperti ikatan sendi-sendi tulang yang saling berhubungan, dan temanya mengalir ke seluruh khotbah seperti aliran darah mengalir ke seluruh tubuh." ${ }^{27}$ Persiapan adalah tuntutan. Jika persiapan asalasalan, makanan yang akan disuguhkan kepada jemaat, bisa mentah, hambar, gosong, setengah matang, keras, lembek, kepedasan, keasinan dan sebagainya.

Dalam buku The Purpose Driven Church, Rick Warren berkata: "Dalam dunia tekhnologi canggih sekarang ini, seringkali berkhotbah dianggap sebagai cara berkomunikasi yang tidak menarik dan sudah kuno. Saya setuju bahwa banyak gaya khotbah yang dahulu berhasil tetapi sekarang sudah kurang efektif. Akan tetapi, dipandang dari segi perubahan yang radikal dalam kehidupan perorangan, tidak ada hal lain yang dapat menggantikan khotbah yang diurapi Roh Kudus."28

\section{Relevan Kini \& Di Sini}

Kegiatan yang hanya konsentrasi pada aspek kompetensi

\footnotetext{
${ }^{26}$ Osborne, Spiral Hermeneutika, 12.

${ }^{27}$ John Koesler, ed., The Moody Hanbook of Preaching (Chicago: Moody Publisher, 2008), 351.
}

(analisis ilmiah) akan mengurung Alkitab menjadi sebuah benda kuno yang tidak relevan, kini dan di sini. Di lain pihak, mengabaikan referensi historikal dan hanya memperhatikan signifikansi yang berguna bagi masa kini juga sama melahirkan problem. Relevan namun tunduk kepada teks!

Mark Labberton, dalam buku Bahaya Ibadah Sejati, berkata: "Jadi apa yang coba kita lakukan? Memastikan supaya kebaktian kita terasa relevan. Kriteria tentang relevan yang tepat mencakup hal-hal seperti kebaktian kontemporer, sound system yang canggih, layar LCD untuk lagulagu, foto-foto, dan klip video. Kita ingin supaya kebaktian kita terdengar dan dirasakan relevan, sama seperti budaya pada umumnya. ${ }^{29}$ Lebih lanjut Labberton berkata: "Bahaya yang sesungguhnya bukanlah bahwa kita terlalu banyak mengejar relevansi, melainkan terlalu sedikit, terlalu banyak tentang budaya kita dan terlalu sedikit tentang Allah." 30

Relevan berarti kaitmengait, bersangkut-paut, berguna secara langsung, penting, erat, cocok, terhubung, sesuai. Dalam hal ini khotbah yang baik itu adalah manakala materinya menjawab atau sesuai kebutuhan audiens. Pemaparan harus bersangkut paut dan terhubung dengan hadirin. Salah satu pertanyaan ketika diundang khotbah di tempat lain adalah: "Siapa yang hadir? Ada hal-hal yang harus menjadi pertimbangan seorang pelayan firman ketika meracik materi khotbah.

Semuanya seputar pendengar, yang terdiri dari berbagai latar bekakang yang beragam (umur,

\footnotetext{
${ }^{28}$ Rick Warren, The Purpose

Driven Church (Malang: Gandum Mas, 2005), 313.

${ }^{29}$ Labberton, Bahaya Ibadah

Sejati, 62.

${ }^{30}$ Ibid., 63.
} 
pendidikan, status social, profesi/ pekerjaan, jenis kelamin, etnis dan sebagainya). Tepat apa yang dimaksud dalam buku Moody Handbook of Preaching, demikian:" Jalan terhadap aplikasi yang cakap merupakan hasil dari pemahaman mendalam dari pola pikir, isu-isu, masalah dan perjuangan masyarakat kontemporer. Sangat penting bahwa komunikator Alkitabiah memahami orang-orang yang hendak dijangkau dan ditolong." 31

\section{Mengabaikan}

situasi

tersebut di atas, menjadikan khotbah tidak mendarat. Jadi menganalisa pendengar adalah penting. Dengan langkah ini pelayan firman dapat mengetahui berapa banyak yang dapat mereka serap dan mengerti dari khotbah yang disampaikan. Sebagaimana seorang gembala yang menuntun domba-domba ke padaang rumput harus tahu kondisi kawanan domba, demikian juga para pelayan firman perlu tahu keadaan jemaat yang hadir.

Yang harus dipahami adalah bahwa berkhotbah sama dengan memberi makan. Khotbah harus selalu berwawasan penggembalaan. Jadi harus nyambung dengan para pendengar, termasuk penyampaian dengan pilihan kata-kata yang dapat dimengerti. Ada godaan untuk memberi kesan bahwa si pelayan firman menguasai bahasa atau bidang tertentu, namun uraian tidak terjangkau untuk dipahami.

Manfaat yang dapat diserap dari nats-nats Alkitab pantas menjadi dorongan bagi para pelayan firman Tuhan untuk serius dan terencana dalam meramu sebuah khotbah. Perhatikan nats berikut: Segala tulisan yang diilhamkan Allah memang bermanfaat untuk mengajar, untuk menyatakan kesalahan, untuk memperbaiki kelakuan dan untuk mendidik orang dalam kebenaran. Dengan demikian tiap-tiap manusia kepunyaan Allah diperlengkapi untuk setiap perbuatan baik (2Tim. 3:16-17). Memberi hikmat; menuntun kepada keselamatan; bermanfaat untuk mengajar; untuk menyatakan kesalahan; untuk memperbaiki kelakuan; untuk mendidik orang dalam kebenaran dan perlengkapan dalam pelayanan. Itu sebabnya Petrus berkata: "Tuhan, kepada siapakah kami akan pergi? Perkataan-Mu adalah perkataan hidup yang kekal..." (Yoh. 6:68).

Alkitab bersifat Ilahi dan diwahyukan secara bertahap, tetapi merupakan kesatuan dan lengkap. Penyelidikan menuntut iman. Alkitab sebagai inspirasi Allah hanya dapat dimengerti dengan iman karena perkara-perkara supranatural di dalamnya.

Alkitab sangat sederhana sehingga orang yang paling tidak berpendidikan pun dapat memahami berita dasarnya namun sekaligus juga begitu mendalam sehingga sarjana yang terbaik pun tidak akan pernah bisa menguak maknanya sepenuhnya.

Douglas Stuart dan Gordon Fee berkata: "Begitu banyak pengkhotbah dan guru terlalu banyak menggali sekitarnya sehingga mengeruhkan air yang ada. Apa yang seharusnya jelas waktu kita membacanya, sekarang menjadi tidak begitu jelas lagi." ${ }^{32}$ Lebih lanjut kedua penulis ini berkata: "Kita juga mengetahui bahwa pengkhotbah atau guru terlalu sering cenderung menggali lebih dahulu baru kemudian melihat, dan dengan demikian ia menutupi pengertian yang jelas dari teks itu yang sering terdapat pada permukaan." 33

Aplikasi adalah pertemuan kebenaran Allah yang kekal dengan

\footnotetext{
${ }^{32}$ Stuart, Hermeneutik, 13.

${ }^{33}$ Ibid.
} 
kehidupan kontemporer. Hati-hati dengan penerapan. Bisa saja menerapkan teks dengan cara yang mungkin membuat penulis Alkitab mengatakan: "Tunggu dulu, itu penerapan yang salah dari apa yang saya maksudkan." Sebuah penyimpangan dari kebenaran yang baik dengan cara yang salah. Teks yang dikeluarkan dari konteks adalah kecerobohan, penyimpangan dan penipuan! Aplikasi terjadi ketika pengkhotbah menemukan jalan dimana tema dari suatu bagian Kitab Suci dan pengalaman manusia bertemu, maka orang akan melihat relevansi Alkitab untuk pengalaman pribadi. Rick Warren berkata:

Berkhotbah yang mengubah hidup mempertemukan kebenaran firman Allah dan kebutuhan-kebutuhan yang nyata dari orang-orang melalui penerapan. Apakah Anda mulai dengan firman Allah atau dengan kebutuhan dirasakan bergantung kepada pendengar Anda. tetap yang sangat penting adalah bahwa pada akhirnya Anda mempertemukan kebenaran firman Allah dan kebutuhan orang-orang melalui penerapan, tidak peduli di mana pesan itu dimulai. ${ }^{34}$

Grant Osborn menekankan pentingnya relevansi teks Kitab Suci dengan situasi modern. Beliau berkata: "Perbedaan antara "apa makna teks yang asli" dan "apa maknanya pada masa kini" semakin diabaikan, tidak diperhatikan atau disangkal" karena adanya pra pemahaman atau "kesadaran diri hermeneutis," dari sang penafsir yang menjadikannya begitu sulit (dan bagi sebagian orang begitu tidak relevan) untuk kembali kepada makna aslinya." ${ }^{\circ 5}$

Firman Allah berbicara kepada semua generasi, maka tidaklah cukup dengan menemukan kembali makna asli yang dimaksud dari suatu perikop tanpa menguraikan signifikansi perikop tersebut bagi zaman sekarang.

Penting diperhatikan bahwa tidak semua catatan di Alkitab langsung relevan kini dan di sini. Sebagai contoh: tidak ada yang merasa terpanggil oleh Roh Kudus untuk mengadakan perjalanan misi ke Troas untuk membawa jubah dan juga kitab-kitab Paulus dari rumah Karpus ke penjaranya di Roma (2Tim. 4:13), walaupun ayat ini jelas-jelas merupakan perintah. Akan tetapi dari surat yang sama kebanyakan orang Kristen percaya bahwa Allah menyuruh mereka dalam masa kesukaran untuk ikut menderita sebagai seorang prajurit yang baik dari Kristus (2:3) - jelas berlaku kini dan di sini!

Seseorang dapat mengambil teks dan secara langsung menerapkannya dalam situasi modern. Dalam beberapa kasus, hal ini berhasil. Contoh: Yesus berkata "kasihilah musuhmu." Para pendengar dapat didiagnosa dengan pertanyaan: "Apakah Anda memiliki musuh?" Jika ya, "kasihilah mereka!" Tetapi ketika orang yang sama membalik halamannya dan menemukan Yesus berkata: "juallah segala yang kamu miliki dan berikanlah kepada orang miskin, dan ikutlah Aku," pasti diperlukan pemikiran serius untuk membawa masalah ini secara langsung, karena jika setiap orang melakukan hal ini, kemungkinan akan muncul berbagai kerumitan.
${ }^{34}$ Warren, The Purpose Driven 
Selain itu adalah benar bahwa Alkitab memiliki sifat yang spesifik, pendangar terdiri dari berbagai latar belakang. Sebagai contoh, sesorang yang sedang mendengar khotbah dapat disamakan dengan Daud yang melakukan perzinahan dengan Betsyeba, tetapi ia bukanlah seorang raja dan ia bukan pemimpin pasukan perang. Teks ini harus dilihat secara spesifik berdasarkan aspek sejarah dan menjelaskan bagaimana Allah yang hidup berbicara kepada orang-orang melalui peristiwa itu.

\section{Kesimpulan}

Alkitab berasal dari Allah sendiri dan berbicara tentang isu-isu yang paling penting dan mendesak di dalam eksistensi umat manusia. Allah menginginkan manusia ciptaan-Nya memahami apa yang Dia katakan. Kitab Suci bukan teka-teki/ huruf sandi yang harus dipecahkan oleh seorang pakar yang berderet gelar akademiknya sebagaimana biasa dilakoni oleh seorang detektif atau agen rahasia. Keseimbangan merupakan tuntutan! Pengkhotbah harus menghindari untuk konsentrasi pada berita, asyik dengan argumen-argumen yang dapat ditemukan dan dibangun, terlepas apakah jemaat mengerti atau berhubungan dengan kehidupan mereka. Adalah logis jika jemaat resah, karena khotbah fokus pada pola penafsiran teks Alkitab yang berkaitan dengan masa lalu di wilayah Israel dan sekitarnya.

Kewaspadaan yang berikut adalah asyik dengan aplikasi yang nampaknya menarik walaupun tidak direstui oleh teks yang dibahas. Tenggelam dengan cerita-cerita, yang sering dikemas dengan istilah kesaksian dan ilustrasi masa kini yang walaupun dapat dipergunakan dalam kehidupan sehari-hari, namun miskin prinsip kebenaran.

Bukan yang penting jemaat senang, bahkan seandainya pun mereka "merasa diberkati dengan khotbah itu. Sesungguhnya khotbah dapat menjadi penghubung atau jembatan emas antara masa lalu dan masa kini.

\section{KEPUSTAKAAN}

[1] Chia, P. S., \& Juanda, J. (2020).

Suffix Study $\imath \alpha$. Journal

KERUGMA, 3(2), 1-4.

[2] Crouch, Andy. Culture Making. Surabaya: Literatur Perkantas Jatim, n.d.

Howard, David M. Kitab-Kitab Sejarah Dalam Perjanjian Lama. Malang: Gandum Mas, 2002.

[3] Kaiser, Walter C. Berkhotbah Dan Mengajar Dari Perjanjian Lama. Bandung: Kalam Hidup, 2009.

[4] Klein, William W.dkk. Introdukction to Biblical Interpretation 1. Malang: Literatur SAAT, 2002.

[5] Koesler, John, ed. The Moody Hanbook of Preaching. Chicago: Moody Publisher, 2008.

[6] Labberton, Mark. Bahaya Ibadah Sejati. Surabaya: Perkantas, 2007.

[7] Maryono, Petrus. Gramatika \& Sintaksis Bahasa Yunani Perjanjian Baru. Yogyakarta: STTII Yogyakarta, 2016.

[8] Osborne, Grant R. Spiral Hermeneutika. Surabaya: Momentum, 2012.

[9] Stuart, Douglas dan Gordon D.Fee. Hermeneutik. Malang: Gandum 
Jurnal Teologi \& Pelayanan ( Kerusso )

E-ISSN: 2714-9587

P-ISSN: 2407-554X

Mas, 2015.

[10] Utley, Bob. Anda Dapat

Memahami Alkitab. Texas: Bible

Lessons International, 2009.

[11] Vines, Jerry \& Shaddix, Jim.

Kuasa Dalam Berkhotbah.

Malang: Gandum Mas, 2002.

[12] Warren, Rick. The Purpose

Driven Church. Malang: Gandum

Mas, 2005.

[13] Zuck, Roy B. Hermeneutik.

Malang: Gandudm Mas, 2014. 